has consistently proved the value of its policies. The range of geneties research reported runs from purely scientific work on Drosophila to studies of the myxomatosis virus, physiology of the coat in cattle concerning sweat glands and hair, to hybrid vigour.

Infective and non-infective diseases important to Australia and disease related to worm and arthropod infestation roceive great attention. The geographical position of Australia has provided a great freedom from some of the devastating diseases of other countries with comparable climatic conditions and wise policy has enabled the position, all round, to be maintained. There are great risks of diseases introduced in the processes of commerce. The important work on bovine contagious pleuro-pneumonia, solidly entrenched in northern parts of the continent for a very long time, is continued. The spocial climatic conditions of the continent have great influence on animal husbandry, and physiological investigations into the means of obtaining the best possible results by attention to the production and management of animals that can thrive and be suitably exploited have been extensively carried out.

\title{
PRIORITIES OF HUMAN RESPONSIBILITY
}

$\mathrm{T}$ HE following statement of policy concerning "Priorities of Human Responsibility" was issued after the fourth meeting of the International Trustees of the World Wildlife Fund which was held in Switzerland recently :

"The World Wildlife Fund believes that man has responsibilities of trusteeship for the natural world over which wo now exercise such sweeping power. How do these responsibilities equate with other human responsibilities? The ending of all forms of human suffering is clearly of paramount importance. We must never waver in the fight against disease, hunger, the threat of war and every other kind of disaster and human misery. We must strive to make a world worth living in for everyone but is a world without wildlife and wild places worth living in? Even when mankind is free from want and fear, will our children's grandchildren thank us if we have sealed off great wild areas of the earth from the Sun with bricks and mortar, concrete and plastics? Wil they have to ask 'What was a wild animal ?' or 'What was a wild place ?'.

"When there is an unavoidable collision betwoon the survival of man and the survival of wildlife, human interests must clearly prevail. It is our thesis, however, that such collisions are rare - that in most cases a little thought, ingenuity and good will can permit the co-existence of man and wildlife without which man himself is so much the poorer. Most of the species exterminated by man in historical times need not have become extinct and would not have done so if anyone had bothered about it. The survival of the dodo and the great auk would not have impoded human progress in the slightost degree.

"Thus the Fund's campaign is not a case of animals versus man. Conservation is for man, for the long-term benofit of humanity, and to ignore it is short-sighted and improvident. There is a close link between medical science and natural science, and an even closer link between the achievement of freedom from hunger and the conservation of wildlife, because both have to do with the proper use of the land and its priceless treasures.

"But there are also responsibilities for adding something constructive and uplifting to human lives as well as for saving them-responsibilities which in the field of conservation, grow daily more urgent, for the wild creatures cannot protest, and once a species becomes extinct nothing can re-create it. Ultimately, therefore, the concern of the World Wildlife Fund is with the future benefit of man and the spiritual enrichment of his life."

\section{THE INTERNATIONAL EPIZOOTICS BUREAU, PARIS}

$\mathrm{T}$ HE report* for 1961-62 by the director, Dr. R. Vittoz, of the International Epizootics Bureau, Paris, made at the thirtieth annual conference, covers incidence of world-wide disease.

The Bureau functions through officials of the countries represented on its council and has a permanent staff in its Paris Office. Reports of its conferences are published in considerable detail and bulletins are issued giving statistical information supplied to that office. From time to time special conferences are called, in addition to the regular seasonal meetings, when particular internationally important problems arise, such as, for example, the break-out of African horse-sickness from the endemic regions in Africa in quite recent years, with great extension from the Middle East into Pakistan. India, and beyond. There is closo association for relevant purposes with other international bodies such as the World Health Organization and the Food and Agriculture Organization of the United Nations. Colloctively, these bodies are able to take most satisfactory action in emergency and, according to circumstances, also in the preparation of short- or long-term plans.

The functions and organizations of these bodies each strengthen the value of the others. Their knowledge of local conditions and circumstances everywhere is very good and detailed, and, with the help of the several

* Report for 1961-62 of the International Epizootics Bureau. Pp. 94. (Paris: Office International des Épizootics, 1962.) countries, rapid and efficient action can be taken when required, experts and materials being mobilized and concentrated to the best advantage.

Many oxamples could be given of the manner in which the functions of the Bureau and of the other organizations with which it works have been utilized. During their existence there have been dangerous extensions of animal disease into countries previously free and, if early and effective action had not been available, losses from devastating disease would undoubtedly have been carried even furthor than was the case, with very serious results to countries with valuable livestock industries.

With the rapid extension of air transport within the memory of serving officials of all countries, and the risks of the possibilities that may arise from space travel in the future, the dangors of infective disease are far greater than in the past. Diseases that the veterinarian had considered to be comfortably tucked away in Africa and limited to that continent have caused very serious losses within the experience of the present working generation of experts. While known to be of the utmost importance. to their endemic areas there had beon little fear that their intorest would be more than academic to workers elsewhere. Blue-tongue of sheep has invaded the United States and at great cost; African swine fever-quite a different virus to the unfortunately well-known scourge of most countries-has invaded the Iberian Peninsula and Mediterranean countries. 